\title{
The association of syphilis with cirrhosis: the role of alcohol and serum hepatitis
}

\author{
F. SADIKALI \\ B.Sc., M.B., M.R.C.P., D.C.H. \\ Department of Medicine, Makerere University Medical School, Kampala, Uganda
}

\begin{abstract}
Summary
The role of syphilis and alcohol was investigated in a prospective study of patients with cirrhosis of liver in Uganda, and results were correlated with the histological type of cirrhosis, and serological tests for hepatitis B antigen (HB Ag). Eighteen out of eighty $(22.5 \%)$ patients with histologically-proven cirrhosis had positive serology for syphilis (VDRL and TPI). A high incidence of alcoholism (80\%) and syphilis $(60 \%)$ was found in patients with micronodular cirrhosis who were all negative for $\mathrm{HB}$ Ag. By contrast, $\mathrm{HB}$ Ag was detected in $37 \%$ of patients with macronodular cirrhosis who had a much smaller incidence of syphilis and alcoholism. Although chronic infection with hepatitis B virus related to $\mathrm{HB}$ Ag appears to be an important factor in the pathogenesis of cirrhosis in at least $30 \%$ of cases, infection acquired during past treatment for syphilis is not an important cause of the association of syphilis with cirrhosis in this population. Subdivision of patients with cirrhosis into those with and those without a history of severe alcohol abuse showed that the difference between the incidence of syphilis in the two groups is significant statistically. However, evidence of syphilis in association with non-alcoholic as well as alcoholic cirrhosis in this and other previously reported series suggests that the association between the two diseases cannot be entirely explained through the common factor of alcoholism, and other factors may also be responsible.
\end{abstract}

\section{Introduction}

There have been numerous reports of the association of syphilis with cirrhosis of liver. Kirmi, Thirkettle and Read (1969), in an extensive review of the literature, found the incidence of syphilis in cirrhosis over the past 100 years to be between 10 and $20 \%$, but could not explain the association. In the past, these two diseases could have occurred together because of syringe-transmitted hepatitis acquired during antisyphilitic treatment (Salaman et al.,

Correspondence: Dr F. Sadikali, Department of Gastroenterology, Victoria Hospital, London, Ontario, Canada NA6 4 G5.
1944; Sheehan, 1944). It is known that acute icteric or non-icteric viral hepatitis can on occasions lead to the development of cirrhosis within 5 years (Krarup and Roholm, 1941; Sherlock, 1948; Klatskin, 1958). However, as no specific tests for serum hepatitis were available until now, the role of this virus in the aetiology of cirrhosis could not be studied.

Cirrhosis and syphilis could also occur together through the factor of alcoholism. Several reports (Scheumacher, 1937; Fleming and Snell, 1942; MacDonald and Mallory, 1958; Wells and Lundberg, 1963) give evidence of excessive consumption of alcohol in patients with both diseases, but no data are available from the earlier series that correlate the syphilis with the histological type of cirrhosis associated with it. For example, it is now generally agreed that micronodular cirrhosis is associated with alcoholism, whilst most macronodular types are not (Sherlock, 1968).

With the discovery of hepatitis B antigen (Blumberg, Alter and Visnich, 1965), sensitive tests have been developed for diagnosis of infection with the virus of 'serum' (long-incubation) hepatitis (Shulman, 1970). A study of the association of $\mathrm{HB} \mathrm{Ag}$ with liver disease has thrown new light on the aetiology of viral hepatitis and cirrhosis in Uganda (Maynard et al., 1970; Anthony et al., 1972; Sadikali, 1972; Sadikali and Barker, 1973). During the course of this prospective study the role of syphilis in patients with cirrhosis was also investigated and an attempt made to correlate the syphilis with the histological type of cirrhosis associated with it, $\mathrm{HB} \mathrm{Ag}$ and alcohol intake.

Patients and methods

All eighty patients were treated in the medical wards of New Mulago Hospital, Kampala, from June 1970 to June 1972. Most of the patients had advanced liver disease with symptoms and signs of hepatocellular failure and/or portal hypertension. A few were admitted for investigation of hepatomegaly or obstructive jaundice due to gall stones. 
The diagnosis of cirrhosis was confirmed in all by liver biopsy (sixty-eight cases), surgical biopsy (three cases) and at autopsy (nine cases). In addition, in seven of the sixty-eight cases subjected to liver biopsy the diagnosis was confirmed at autopsy. The histological type of cirrhosis was defined as nutritional (micronodular), or macronodular (posthepatitic, postnecrotic, and 'mixed' types) according to the criteria of Gall (1960), which have been described in an earlier paper correlating $\mathrm{HB} \mathrm{Ag}$ with the histopathology of cirrhosis in Uganda (Anthony et al., 1972). Patients were carefully questioned about a past history suggestive of viral hepatitis, genital chancre, treatment for syphilis, and alcohol intake. The standard Venereal Disease Reference Laboratory test (VDRL) was done in all cases and, when positive, Reiter's Protein Complement Fixation test (RPCFT) was also performed. Sera from all patients were frozen and stored at $-20^{\circ} \mathrm{C}$. The diagnosis of syphilis was confirmed in the VDRL positive sera by the Treponema pallidum Immobilization test (TPI). The tests for $\mathrm{HB} \mathrm{Ag}$ were done on stored sera by the
Complement Fixation and Counterelectrophoretic techniques (Shulman and Barker, 1969; Gocke and Howe, 1970).

\section{Results}

Twenty of the eighty ( $25 \%$ ) patients had a positive or weakly positive VDRL (Table 1). Eighteen $(22.5 \%)$ were confirmed as having syphilis by the TPI test. Reiter's test was positive in nine, negative in five and anticomplementary in the rest. Fifteen of the eighty patients had nutritional (micronodular) cirrhosis, the remainder posthepatic, postnecrotic or mixed type of (macronodular) cirrhosis. Results of serological tests for syphilis, $\mathrm{HB} \mathrm{Ag}$, and the incidence of alcoholism in the two types of cirrhosis are shown in Table 2 . Of the fifteen with micronodular cirrhosis, nine $(60 \%)$ had positive tests for syphilis (positive VDRL and TPI). In contrast, only nine of sixty-five $(14 \%)$ with the macronodular type had positive serology. This difference is significant $(P<0.001)$. None of the fifteen with micronodular cirrhosis was positive for $\mathrm{HB} \mathrm{Ag}$ (positive CF and/or

TABLE 1. Clinical data and serological results in cirrhosis with syphilis

\begin{tabular}{|c|c|c|c|c|c|c|c|c|c|c|c|}
\hline \multirow{2}{*}{$\begin{array}{c}\text { Series } \\
\text { no. }\end{array}$} & \multirow[b]{2}{*}{ Sex } & \multirow{2}{*}{$\begin{array}{c}\text { Age } \\
\text { (years) }\end{array}$} & \multirow{2}{*}{$\begin{array}{l}\text { Type of } \\
\text { cirrhosis }\end{array}$} & \multirow{2}{*}{$\begin{array}{c}\text { Past } \\
\text { chancre } \\
\text { treatment }\end{array}$} & \multirow{2}{*}{$\begin{array}{c}\text { Past } \\
\text { jaundice }\end{array}$} & \multirow{2}{*}{$\begin{array}{l}\text { Alcohol } \\
\text { intake }\end{array}$} & \multicolumn{3}{|c|}{ Syphilis serology } & \multicolumn{2}{|c|}{ HAA } \\
\hline & & & & & & & VDRL & RPCFT & TPI & $\mathrm{CF}$ & CEP \\
\hline 2 & $\mathbf{F}$ & 28 & Nutr. & No & No & $+t+$ & weak + & $\mathrm{A} / \mathrm{C}$ & weak + & $\mathrm{A} / \mathrm{C}$ & - \\
\hline 9 & $\mathbf{F}$ & 50 & Nutr. & No & No & $t+t$ & + & $\mathrm{A} / \mathrm{C}$ & + & $\mathrm{A} / \mathrm{C}$ & - \\
\hline 12 & $\mathbf{M}$ & 35 & Mixed & No & No & $+t+$ & + & + & + & $\mathrm{A} / \mathrm{C}$ & - \\
\hline 18 & $\mathbf{M}$ & 57 & Nutr. & Yes & No & $t+t$ & + & + & weak - & $\mathrm{A} / \mathrm{C}$ & - \\
\hline 20 & $\mathrm{~F}$ & 49 & Mixed & No & Yes & + & + & + & weak + & $\mathrm{A} / \mathrm{C}$ & - \\
\hline 25 & $\mathbf{M}$ & 60 & Mixed & No & No & $+t+$ & weak + & + & weak + & 80 & + \\
\hline 30 & $\mathbf{M}$ & 35 & Nutr. & Yes & No & $1++$ & weak + & + & + & - & - \\
\hline 35 & $\mathbf{M}$ & 35 & Nutr. & No & No & + & + & + & $t$ & - & - \\
\hline 38 & $\mathbf{M}$ & 27 & Postnec. & No & No & No & weak + & - & + & 32 & + \\
\hline 40 & $\mathbf{M}$ & 45 & Nutr. & No & No & $+t+$ & + & - & + & - & - \\
\hline 47 & $\mathbf{M}$ & 57 & Postnec. & No & Yes & +++ & weak + & $\mathrm{A} / \mathrm{C}$ & t- & 256 & + \\
\hline 49 & $\mathbf{M}$ & 44 & Mixed & No & No & + & $-t$ & - & t. & - & - \\
\hline 52 & $\mathbf{F}$ & 46 & Nutr. & Yes & No & No & + & - & + & - & - \\
\hline 55 & $\mathbf{M}$ & 35 & Nutr. & No & Yes & $t+t$ & + & + & -1 & - & - \\
\hline 59 & $\mathbf{M}$ & 45 & Mixed & No & Yes & No & + & - & Neg. & - & - \\
\hline 61 & $\mathbf{M}$ & 22 & Mixed & No & Yes & + & weak + & + & Inc. & - & - \\
\hline 64 & $\mathbf{M}$ & 55 & Mixed & Yes & No & $+t+$ & weak + & $\mathrm{A} / \mathrm{C}$ & + & $\mathrm{A} / \mathrm{C}$ & - \\
\hline 67 & $\mathbf{F}$ & 30 & Postnec. & No & No & No & + & $\mathrm{A} / \mathrm{C}$ & + & 4 & + \\
\hline 71 & $\mathbf{M}$ & 22 & Posthep. & No & No & $+t+$ & + & $\mathrm{A} / \mathrm{C}$ & 1 & 16 & + \\
\hline 78 & $\mathbf{F}$ & 35 & Nutr. & No & No & $+t+$ & + & + & + & - & - \\
\hline
\end{tabular}

$\mathrm{A} / \mathrm{C}=$ anticomplementary; Neg. = negative; Inc. = inconclusive; Nutr. = nutritional; Postnec. = postnecrotic; Posthep. = posthepatic; Alcohol intake $+++=$ chronic alcoholism, $+=$ mild to moderate intake.

TABLE 2. Alcoholism, syphilis and $\mathrm{HB}$ Ag in cirrhosis

\begin{tabular}{|c|c|c|c|c|c|c|c|}
\hline \multirow[b]{2}{*}{ Type of cirrhosis } & \multirow{2}{*}{$\begin{array}{l}\text { No. of } \\
\text { cases }\end{array}$} & \multicolumn{2}{|c|}{ Alcoholism } & \multicolumn{2}{|c|}{ HB Ag positive } & \multicolumn{2}{|c|}{$\begin{array}{l}\text { VDRL and TPI } \\
\text { positive }\end{array}$} \\
\hline & & No. & $\%$ & No. & $\%$ & No. & $\%$ \\
\hline $\begin{array}{l}\text { Nutritional (micronodular) } \\
\text { Macronodular }\end{array}$ & $\begin{array}{l}15^{*} \\
65^{*}\end{array}$ & $\begin{array}{r}12 \\
7\end{array}$ & $\begin{array}{l}80 \\
11\end{array}$ & $\begin{array}{r}0 \\
24\end{array}$ & $3 \overline{7}$ & $\begin{array}{l}9 * \\
9^{*}\end{array}$ & $\begin{array}{l}60 \\
14\end{array}$ \\
\hline Total cirrhosis & 80 & 19 & 24 & 24 & 30 & 18 & $22 \cdot 5$ \\
\hline
\end{tabular}

$* P<0.001$. 
CEP), whilst twenty-four of sixty-five (37\%) with macronodular cirrhosis were found to be carriers of the antigen. Five patients had positive serological tests for syphilis as well as $\mathrm{HB}$ Ag.

\section{Discussion}

With few exceptions, previous reports which have suggested the association between syphilis and cirrhosis were based mainly upon a past history of a genital chancre and/or a past history of treatment for syphilis. Even in the few instances where the Wasserman reaction (WR) was used, results of the serological tests were often not recorded. Because of the Biological False-Positive (BFP) phenomenon in patients with abnormal plasma proteins (Moore, 1956), a certain number of positive WRs may be expected to be of this type (Knight and Wilkinson, 1963). It is, therefore, necessary to confirm the diagnosis of syphilis with the more reliable TPI test. Apart from the report by Kirmi et al. (1969), this has not been done in any previous studies. The VDRL was used as a screening test in the present work and was found to be a useful indicator of syphilis as TPI was positive in all except two VDRL positive sera. In one of those who had positive VDRL and RPCFT, the TPI was inconclusive but probably positive. The second patient had positive VDRL, but both RPCFT and TPI were negative. Presumably he had a biological false-positive VDRL. Thus, it appears that despite the very high levels of serum globulins the biological false-positive VDRL is not a common finding in cirrhosis. On the other hand, RPCFT proved to be unreliable as a confirmatory test mainly because of anticomplementary reactions, but the test was negative in four out of the eighteen cases who were shown to have positive VDRL and TPI tests. This is not surprising as in syphilis of long duration whether treated or untreated, RPCFT may give false-negative reactions in $50 \%$ of cases (Nicholas and Beerman, 1963).

The incidence of treponemal antibodies $(22.5 \%)$ in cirrhosis in the present series is very much higher than the $1.0 \%$ incidence in 14,223 blood donors from an area of 40-mile radius around Kampala, reported by Masawe (1970), who also reviewed the evidence that this truly reflects an incidence of treponemal antibodies in the control population of Uganda of between 1 and $1.3 \%$. The results in this study, therefore, confirm that there is an association between syphilis and cirrhosis in this population. None of the patients with positive serology had any evidence of healed or active cutaneous lesions of yaws or pinta. These conditions are extremely rare in Uganda, and can be excluded as a cause of positive serology. Histological analysis showed that serological evidence of syphilis is found mostly in patients with micronodular cirrhosis (Table 2). No definite data are available from past reports that correlate syphilis with the type of cirrhosis associated with it. In any case analysis of many of the earlier series is complicated by the inclusion of patients with only a past history and/or treatment for syphilis with no serological or histological confirmation of the diagnosis. Also many of the previous studies were retrospective or based on clinical diagnosis only, so that the type of cirrhosis and alcohol intake were often uncertain (Table 3 ).

We have previously shown that as in other locations, micronodular cirrhosis in Uganda is associated with alcoholism whilst most macronodular types are not (Anthony et al., 1972). On occasions, however, progression of alcoholic cirrhosis to the postnecrotic (macronodular) variety occurs (Popper et al., 1960). This may partly account for the relatively high incidence of syphilis even in association with macronodular cirrhosis in this and other series (Boles and Clark, 1936; MacDonald and Mallory, 1958; Miyai and Ruebner, 1963; Wells and Lundberg, 1963). At least five of our nine patients with macronodular cirrhosis and syphilis gave a history of chronic alcoholism, and only two denied ever taking alcohol. Subdivision of all cases into those with and those without a history of severe alcohol abuse showed that the incidence of syphilis in the two groups is significantly different (Table 4).

Hepatitis B antigen was not detected in any patient with micronodular cirrhosis (Table 2), which is consistent with the predominant role of alcohol in this type of cirrhosis. By contrast $37 \%$ of patients with macronodular cirrhosis had positive tests for $\mathbf{H B ~} \mathbf{A g}$ compared to the $3 \%$ incidence in control patients without liver disease, and there is impressive evidence that chronic infection with serum hepatitis virus is an important factor in the pathogenesis of at least $40 \%$ of macronodular cirrhosis in Uganda (Maynard et al., 1970; Anthony et al., 1972; Sadikali, 1972). However, the present clinical data do not suggest that the infection was acquired during past treatment for syphilis. Amongst those with syphilis only five were positive for $\mathrm{HB} \mathrm{Ag}$ and all five denied a past history of treatment for syphilis, injections, or blood transfusions. Three of them did have a history of severe alcohol abuse so that the combined factors of alcoholism and hepatitis were probably responsible for cirrhosis in these three cases. On the other hand, the four patients in this series who had been previously treated for syphilis and had positive VDRL and TPI, were all negative for $\mathrm{HB} \mathrm{Ag}$. In the majority of our patients with $\mathrm{HB}$ Ag-positive cirrhosis and hepatitis, there was no evidence for transmission of the infection by injection or blood transfusion (Anthony et al., 1972; Sadikali and Barker, 1973). Insect-borne transmission of hepatitis B was suspected from epidemiological data in tropical 
TABLE 3. Syphilis and alcoholism in previous series

\begin{tabular}{|c|c|c|c|}
\hline Authors & $\begin{array}{l}\text { No. and type of } \\
\text { cirrhosis }\end{array}$ & $\begin{array}{l}\text { Alcoholism } \\
(\%)\end{array}$ & $\begin{array}{c}\text { Total \% } \\
\text { with syphilis }\end{array}$ \\
\hline $\begin{array}{l}\text { Chapman, Snell and } \\
\text { Rowntree (1933) }\end{array}$ & $\begin{array}{l}\text { Fifty-eight, clinical or } \\
\text { surgically confirmed }\end{array}$ & 43 & 17 \\
\hline Rao (1933) & Sixty-five, portal cirrhosis & 3 & 48 \\
\hline Yenikomshian (1934) & $\begin{array}{l}\text { Seventy, clinical/ } \\
\text { non-alcoholic }\end{array}$ & 0 & 12 \\
\hline Boles and Clark (1936) & $\begin{array}{l}243 \text {, mixed types at } \\
\text { autopsy }\end{array}$ & 30 & 12 \\
\hline Scheumacher (1937) & $\begin{array}{l}\text { Forty-four, diffuse type } \\
\text { at autopsy }\end{array}$ & 50 & 29 \\
\hline Evans and Gray (1938) & $\begin{array}{l}217, \text { mixed types at } \\
\text { autopsy }\end{array}$ & 27 & 12 \\
\hline Fleming and Snell (1942) & 200 , clinical cases & 43 & 16 \\
\hline Ratnoff and Patek (1942) & $\begin{array}{l}386, \text { mixed and clinical } \\
\text { cases }\end{array}$ & 54 & 16 \\
\hline $\begin{array}{l}\text { MacDonald and Mallory } \\
\text { (1958) }\end{array}$ & $\begin{array}{l}221, \text { mixed cases at } \\
\text { autopsy }\end{array}$ & 35 & 23 \\
\hline $\begin{array}{l}\text { Miyai and Ruebner } \\
\text { (1963) }\end{array}$ & $\begin{array}{l}249 \text {, portal type; } \\
177 \text { post-necrotic }\end{array}$ & $\begin{array}{r}65 \\
6\end{array}$ & 18 \\
\hline $\begin{array}{l}\text { Manderson, Patrick and } \\
\text { Peters (1965) }\end{array}$ & $\begin{array}{l}\text { Forty-nine, hepatoma } \\
\text { with cirrhosis }\end{array}$ & 22 & 10 \\
\hline Kirmi et al. (1969) & $\begin{array}{l}\text { Forty-nine, biopsies } \\
\text { (type not stated) }\end{array}$ & 30 & 13 \\
\hline
\end{tabular}

TABLE 4. Syphilis in cirrhosis with and without alcoholism

\begin{tabular}{lccc}
\hline & No. of & \multicolumn{2}{c}{ VDRL and TPI positive } \\
\cline { 3 - 4 } & cases & No. & $\%$ \\
\hline Alcoholism & $19^{*}$ & $12^{*}$ & 63 \\
No alcoholism & $61^{*}$ & $6^{*}$ & 10 \\
Total cirrhosis & 80 & 18 & 22.5 \\
\hline & $* P<0.001$
\end{tabular}

countries (Blumberg et al., 1970), and has been supported by the finding of $\mathrm{HB} \mathrm{Ag}$ in wild-caught mosquitoes in Kenya and Uganda (Prince et al., 1972). Hepatitis B antigen has also been demonstrated in urine, faeces, and saliva (Blainey et al., 1971; Grob and Jemelka, 1971; Ward et al., 1972) and evidence has also recently been presented for respiratory and sexual transmission (Almeida et al., 1971; Heathcote and Sherlock, 1973).

The importance of serological testing for syphilis, particularly in alcoholic cirrhosis, is again emphasized (Lancet, 1970). None of our eighteen proven cases of syphilis had any clinical signs or symptoms of the disease, and only four had received treatment for it. Liver biopsies from patients with syphilis showed no changes that suggested specific syphilitic involvement. Thus, it appears that regardless of the histological type there is an association of syphilis with cirrhosis in some patients through the common factor of alcoholism, but there are large numbers of patients with syphilis and cirrhosis who have never taken alcohol (Rao, 1933; Yenikomshian, 1934; Boles and Clark, 1936; Ratnoff and Patek, 1942; Kirmi et al., 1969). In the present series, there were also at least six patients with syphilis and cirrhosis who had no evidence of alcohol abuse (Table 4); there must therefore be a further factor involved, and scarring following severe hepatic secondary syphilis which was untreated does seem a possibility. Studies for syphilis in alcoholics with cirrhosis and a similar control group of alcoholics without cirrhosis are also required to exclude the possibility of syphilis in association with alcoholism predisposing to cirrhosis as suggested by Scheumacher (1937).

Recently the increased titres of antibodies to many viral and bacterial antigens in patients with chronic liver disease (Cross et al., 1971; Protell et al., 1971; Bjorneboe, Prytz and Orskov, 1972) have received considerable attention. However, the statistically different incidence of syphilis in alcoholic and nonalcoholic cirrhosis in the present series indicates that the positive syphilis serology could not be due to this non-specific phenomenon (Triger, Alp and Wright, 1973).

\section{Acknowledgments}

I would like to thank Dr C. L. Vogel of the Uganda Cancer Institute, Kampala, for help in storing sera, Dr G. Lomholt of Dermatology Section, Mulago Hospital, Kampala, for his valuable criticism and advice, Dr H. Aage Nielsen, Department of Treponematoses, Statens Seruminstitut, Copenhagen, Denmark, for doing the TPI test in the VDRL-positive sera, Dr P. P. Anthony, Department of Pathology, Makerere 
University Medical School, Kampala, and Dr L. F. Barker, Division of Blood and Blood Products, Food and Drug Administration, Rockville, Maryland, U.S.A., who collaborated in the study of $\mathrm{HB} \mathrm{Ag}$ with liver disease in Uganda.

\section{References}

Aleida, J.D., Kulatiloke, A.E., Mackay, D.H., Shack man, R., Chisholm, G.D., MacGregor, A.B., O'DonoGhue, E.P.N. \& Waterson, A.P. (1971) Possible airborne spread of serum hepatitis within a haemodialysis unit. Lancet, ii, 849.

Anthony, P.P., Vogel, C.L., Sadikali, F., Barker, L.F. \& Peterson, M.R. (1972) Hepatitis-associated antigen and antibody in Uganda: correlation of serological testing with histopathology. British Medical Journal, i, 403.

Bjorneboe, M., Prytz, H. \& Orskov, F. (1972) Antibodies to intestinal microbes in serum of patients with cirrhosis of liver. Lancet, i, 58.

Blainey, J.D., Earle, A., Flewett, T.H. \& Williams, L.K.L. (1971) Is the urine infective in serum hepatitis? Lancet, i, 797.

Blumberg, B.S., Alter, M.J. \& Visnich, S. (1965) A 'new' antigen in leukemia sera. Journal of the American Medical Association, 191, 541.

Blumberg, B.S., Sutnick, A.I., London, W.T. \& Millman, I. (1970) Australia antigen and hepatitis. New England Journal of Medicine, 283, 349.

Boles, R.S. \& Clark, J.H. (1936) The role of alcohol in cirrhosis of liver. Journal of the American Medical Association, 107, 1200.

Chapman, C.B., Snell, A.M. \& Rowntree, L.G. (1933) Compensated cirrhosis of liver. Journal of the American Medical Association, 100, 1735.

Closs, O., Haukenes, G., GJone, E. \& Blomhoff, J.P. (1971) Raised antibody titres in liver disease. Lancet, ii, 1202.

LANCET (1970) Syphilis and cirrhosis. Editorial. Lancet, i, 28.

Evans, N. \& Gray, P.A. (1938) Laennec's cirrhosis. Journal of the American Medical Association, 110, 1159.

Fleming, R.G. \& Snell, A.M. (1942) Portal cirrhosis with ascites: an analysis of 200 cases with special reference to prognosis and treatment. American Journal of Digestive Diseases, 9, 115.

GALL, E.A. (1960) Posthepatitic, postnecrotic and nutritional cirrhosis: a pathologic diagnosis. American Journal of Pathology, 36, 241.

Gocke, D.J. \& HowE, C. (1970) Rapid detection of Australia antigen by counter immunoelectrophoresis. Journal of Immunology, 104, 1031.

Grob, P.J. \& JemelKa, H. (1971) Faecal S.H. (Australia) antigen in acute hepatitis. Lancet, i, 206.

Heathcote, J. \& Sherlock, S. (1973) Spread of acute type-B hepatitis in London. Lancet, i, 1468.

Kirmi, G., Thirkettle, J.L. \& Read, A.E.A. (1969) The association of syphilis with hepatic cirrhosis: a report of six cases and a review of the literature. Postgraduate Medical Journal, 45, 675.

Klatskin, G. (1958) Subacute hepatic necrosis and postnecrotic cirrhosis due to anicteric infections with the hepatitis virus. American Journal of Medicine, 25, 333.

KNIGHT, A. \& Wilkinson, R.D. (1963) The clinical significance of the biological false positive reactor: a study of 113 cases. Canadian Medical Association Journal, 88, 1193.

KraRUP, N.B. \& RoHOLM, K. (1941) The development of cirrhosis of liver after acute hepatitis, elucidated by aspiration biopsy. Acta medica scandinavica, 108, 306.
Macdonald, R.A. \& Mallory, G.K. (1958) The natural history of postnecrotic cirrhosis: a study of 221 autopsy cases. American Journal of Medicine, 24, 334.

Manderson, W.G., Patrick, R.S. \& Peters, E.E. (1965) Primary carcinoma of liver, a survey of cases admitted to Glasgow Royal Infirmary during 1949-1963. Scottish Medical Journal, 10, 60.

MASAWE, A.E.J. (1970) Serological tests for syphilis in Uganda. East African Medical Journal, 47, 673.

MaYNARD, E.P., SADikali, F., ANTHONY, P.P. \& Barker, L.F. (1970) Hepatitis-associated antigen and cirrhosis in Uganda. Lancet, ii, 1316.

MiYAi, K. \& RuebneR, B.H. (1963) Acute yellow atrophy, cirrhosis and hepatoma. Archives of Pathology, 75, 609.

Moore, J.E. (1956) Venereology in transition. British Journal of Venereal Disease, 32, 217.

Nicholas, L. \& Beerman, H. (1965) Present day serological diagnosis of syphilis: a review of some of the recent literature. American Journal of Medical Science, 249, 466.

Popper, H., Rubin, E., Krus, S. \& SchaffNer, F. (1960) Postnecrotic cirrhosis in alcoholics. Gastroenterology, 39, 669.

Prince, A.M., Metsellar, D., Kafuko, G.W., Mukwata, L.G., LiNG, C.M. \& OverbY, L.R. (1972) Hepatitis B antigen in wild-caught mosquitoes in Africa. Lancet, ii, 247.

Protell, R.L., Soloway, R.D., Martin, W.J., SchoenFIELD, L.J. \& SUMmerSKILL, W.H.J. (1971) Antisalmonella agglutinins in chronic active liver disease. Lancet, ii, 330.

RAO, R. (1933) An investigation into the compensated portal cirrhosis. Indian Journal of Medical Research, 21, 389.

Ratnoff, O.D. \& Patek, A.J. (1942) The natural history of Laennec's cirrhosis of the liver. Medicine, 21, 207.

SADIKALI, F. (1972) Hepatitis-associated antigen and acute and chronic liver disease in Uganda. East African Medical Journal, 49, 782.

Sadikali, F. \& Barker, L.F. (1973) Hepatitis-associated antigen and antibody, and acute viral hepatitis in Uganda. African Journal of Medical Science, 4, 7.

Salaman, M.H., King, A.J., Williams, D.I. \& Nicol, C.S. (1944) Prevention of jaundice resulting from antisyphilitic treatment. Lancet, ii, 7.

Scheumacher, G.A. (1937) Causative factors in production of Laennec's cirrhosis with special reference to syphilis. American Journal of Medical Science, 194, 693.

SheEHAN, H.L. (1944) Epidemiology of infective hepatitis. Lancet, ii, 8.

SHERLOCK, S. (1948) Posthepatitis cirrhosis. Lancet, i, 817.

SHERLOCK, S. (1968) Diseases of the Liver and Biliary System. Fourth edition, p. 401. Blackwell Scientific Publications: Oxford.

Shulman, N.R. (1970) Hepatitis-associated antigen. American Journal of Medicine, 49, 669.

Shulman, N.R. \& BARKER, L.F. (1969) Virus-like antigen, antibody and antigen-antibody complexes in hepatitis measured by complement fixation. Science, 165, 304.

Triger, D.R., AlP, M.H. \& Wright, R. (1973) Hyperglobulinaemia in liver disease. Lancet, i, 1494.

Ward, R., Borchert, P., Wright, A. \& Kline, E. (1972) Hepatitis B antigen in saliva and mouth washings. Lancet, ii, 726.

Wells, R.F. \& LundBerG, G.D. (1963) Hepatoma: a review of 43 cases with comments on syphilis as an aetiological factor. Gastroenterology, 44, 598.

Yenikomshian, H.A. (1934) Nonalcoholic cirrhosis of the liver in Lebanon and Syria. Journal of the American Medical Association, 103, 660. 